\title{
A NUMERICAL EXPERIMENT \\ FOR THE BARENBLATT - ZHELTOV - KOCHINA EQUATION IN A BOUNDED DOMAIN
}

P. O. Moskvicheva, South Ural State University, Chelyabinsk, Russian Federation, pelageia@bk.ru

An investigation of the stability of Sobolev type equations undoubtedly is an actual problem, since these equations, with various conditions, model a multitude of processes. For example, the Barenblatt - Zheltov - Kochina model describes such processes as, for example, filtration and thermal conductivity. In this paper we consider the Cauchy-Dirichlet problem for equation in a bounded domain.

We shall understand stability in the sense of Lyapunov A. M. The aim of this paper is to obtain conditions under which the stationary solution of our problem will be stable and asymptotically stable. The obtained conditions are formulated in the theorem. In addition, an algorithm of the computational experiment will be described to illustrate the instability in the case when the conditions of the theorem are not satisfied. We note that here we apply the method of the Lyapunov functional modified for the case of complete normed spaces. The computational experiment is based on the Galerkin method.

Keywords: Sobolev type equations, stability.

\section{Introduction}

The Barenblatt - Zheltov - Kochina equation

$$
(\lambda-\Delta) u_{t}=\alpha \Delta u
$$

simulates the pressure dynamics of the fuid filtered in fractured porous medium [1], processes of moisture transfer in a ground [2] and processes of the solid-to-fluid thermal conductivity in the environment with two temperatures [3]. Here the parameters $\lambda \in \mathbb{R}$, $\alpha \in \mathbb{R}_{+}$.

Let $\Omega \subset \mathbb{R}^{n}, n \in \mathbb{N}$ - be a bounded domain with a boundary $\partial \Omega$ of class $C^{\infty}$. Our goal is to find the function $u=u(x, t), x \in \Omega, t \in \mathbb{R}$, that satisfies conditions

$$
\begin{gathered}
u(x, t)=u_{0}(x), \quad x \in \Omega, \\
u(x, t)=0, \quad(x, t) \in \partial \Omega \times \mathbb{R} .
\end{gathered}
$$

Our goal is to study the stability of a unique (zero) stationary solution of this problem (1)-(3).

The foundations of the theory of stability of Sobolev type equations are formulated in [4], [5]. In these papers, dichotomies of linear Sobolev type equations were studied. In article [6] the exponential dichotomies of solutions of the Barenblatt - Zheltov - Kochina equation defined on a geometric graph are described. In [7] the method of the Lyapunov functional modified for complete normed spaces was described in detail.

The goal of this paper is an analytical study of the stability of the problem (1)-(3), as well as a computational experiment to illustrate the instability of this problem under certain conditions. we will reduce the problem (1)-(3) to the Cauchy problem 


$$
u(0)=u_{0}
$$

for an abstract linear homogeneous equation of Sobolev type

$$
L \dot{u}=M u .
$$

Then we apply the theory of $p$-bounded operators.

This article consists of an introduction, three parts and a list of literature. In the first part, the phase space of the Barenblatt - Zheltov - Kochina equation is described, in the second, the stability and asymptotic stability theorem for this equation is formulated. The third part is devoted to the description of a computational experiment. A specific example is also considered here.

\section{Phase space}

Reducing the problem (1)-(3) to (4)-(5). We will use the results from [8]. Consider the spaces

$$
\mathfrak{U}=\left\{u \in W_{p}^{k+2}(\Omega): u(x)=0, x \in \partial \Omega\right\}, \quad \mathfrak{F}=W_{p}^{k}(\Omega), 1<p<\infty, k=0,1 \ldots
$$

and operators $L=\lambda-\Delta: \mathfrak{U} \rightarrow \mathfrak{F}, \quad M=\alpha \Delta: \mathfrak{U} \rightarrow \mathfrak{F}$.

The $L$-spectrum of the operator $M$ is $\sigma^{L}(M)=\left\{\mu_{k}=\frac{\alpha \lambda_{k}}{\lambda-\lambda_{k}}: k \in \mathbb{N} \backslash\left\{l: \lambda_{k}=\lambda\right\}\right\}$. It is limited, because $\lim _{k \rightarrow \infty} \mu_{k}=\alpha$.

We prove the $(L, 0)$-boundedness of the operator $M$. Consider two different cases.

First let $\lambda \notin\left\{\lambda_{k}\right\}$. Then ker $L=\{0\}=\mathfrak{U}^{0}, \mathfrak{U}^{1}=\mathfrak{U}, \mathfrak{F}^{2}=M[\operatorname{ker} L]=\{0\}, \mathfrak{F}^{1}=\mathfrak{F}$, and obviously $\mathfrak{F}^{1} \oplus \mathfrak{F}^{2}=\mathfrak{F}$.

Then let $\lambda \in\left\{\lambda_{k}\right\}$, then $\operatorname{ker} L=\operatorname{span}\left\{\varphi_{\mathrm{k}}: \lambda_{\mathrm{k}}=\lambda\right\}$. Lets construct $\mathfrak{F}^{1}$ and $\mathfrak{F}^{2}$. We will find the projector

$$
Q=\mathbb{I}-\sum_{\lambda_{k}=\lambda}\left\langle\cdot, \varphi_{k}\right\rangle \varphi_{k}
$$

Using this projector we will find space $\mathfrak{F}^{1}=\left\{f \in \mathfrak{F}:\left\langle f, \varphi_{k}\right\rangle=0, \lambda_{k}=\lambda\right\}$. The space $\mathfrak{F}^{2}=M[\operatorname{ker} L]=\operatorname{span}\left\{\varphi_{\mathrm{k}}: \lambda_{\mathrm{k}}=\lambda\right\}$. It's obvious that $\mathfrak{F}^{1} \oplus \mathfrak{F}^{2}=\mathfrak{F}$.

It means that for all $\alpha \in \mathbb{R} \backslash\{0\}, \lambda \in \mathbb{R}$ operator $M$ is $(L, 0)$-bounded. Hence there exists a unique resolving group of equation (1).

Definition 1. The solution of equation (5) is a vector-function $u \in C^{\infty}\left(\mathbb{R}_{+} ; \mathfrak{U}\right)$, that satisfies this equation. The solution of equation (5) is called the solution of the Cauchy problem

$$
u(0)=u_{0}
$$

if it satisfies (6).

Definition 2. The set $\mathfrak{P} \subset \mathfrak{U}$ is called the phase space of equation (5), if

(i) any solution $u=u(t)$ of equation (5) contained in the set $\mathfrak{P}$, i.e. $u(t) \in \mathfrak{P} \forall t \in \mathbb{R}$;

(ii) for any $u_{0} \in \mathfrak{P}$ there is a unique solution $u \in C^{\infty}(\mathbb{R} ; \mathfrak{U})$ of the Cauchy problem $u(0)=u_{0}$ for equation $(5)$.

In order to find the phase space of equation (1), we use the following theorem. 
Theorem 1. Let operator $M$ is $(L, p)$-bounded. Then the space $\mathfrak{U}^{1}$ is the phase space of equation (5).

Construct a projector $P$ in order to find the space $\mathfrak{U}^{1}$.

$$
P=\left\{\begin{array}{l}
\mathbb{I}, \text { if } \lambda \notin\left\{\lambda_{k}\right\} ; \\
\mathbb{I}-\sum_{\lambda_{k}=-\lambda}\left\langle\cdot, \varphi_{k}\right\rangle \varphi_{k}, \text { if } \lambda \in\left\{\lambda_{k}\right\} .
\end{array}\right.
$$

Thus, we have proved the theorem.

Theorem 2. For any $\alpha \in \mathbb{R} \backslash\{0\}$ and

(i) $\lambda \in \mathbb{R} \backslash\left\{\lambda_{k}\right\}$ the phase space of the equation (1) is the entire space $\mathfrak{U}$;

(ii) $\lambda \in\left\{\lambda_{k}\right\}$ the phase space of the equation (1) is the entire space $\mathfrak{U}^{1}=\left\{u \in \mathfrak{U}:\left\langle u, \varphi_{k}\right\rangle=0, \lambda_{k}=\lambda\right\}$.

Remark 1. Many papers are devoted to the study of phase spaces for various models, see for example $[9,10,11]$.

\section{Stability}

We define the norm in $L_{2}$ in the space $\mathfrak{U}$. If we fill the space $\mathfrak{U}$ of this norm, then we get the space $L_{2}$. But the phase space of our problem is space $\mathfrak{U}$. Thus, in what follows we shall consider a normed space $\mathfrak{U}$.

Let $\mathfrak{U}$ be a normed space. The family of mappings $S$ is called a nonlinear semigroup in a normed space $\mathfrak{U}$ if for every $u \in \mathfrak{U}$ and some $\tau=\tau(u) \in \mathbb{R}_{+}$the following conditions are satisfied

(i) $S=S(t, u) \in \mathfrak{U}$, for all $t \in(-\tau ; \tau) ; S(0, u)=u$;

(ii) $S(t+s, u)=S(t, S(s, u))$ for all $t+s \in(-\tau, \tau)$.

A point $u \in \mathfrak{U}$, such that

(iii) $S(t, u)=u, t \in \mathbb{R}$,

is called a stationary point.

On the space $\mathfrak{U}$ there exists a nonlinear semigroup

$$
S(t, u)=\frac{1}{2 \pi i} \int_{\gamma} R_{\mu}^{L}(M) u e^{\mu t} d \mu, t \in \mathbb{R} .
$$

A contour $\gamma$ is closed curve and the domain bounded by this contour contains the $L^{-}$ spectrum $\sigma^{L}(M)$ of operator $M$.

Obviously, zero point is a stationary point.

Definition 3. A stationary point $u$ is called

(i) stable (in sense of A.M. Lyapunov), if for any neighborhood $O_{u}$ of $u$ there exists a neighborhood $O_{u}^{\prime}$ (i.e. not necessarily the same neighborhood) of the same point, such that $S(t, v) \in O_{u}^{\prime}$ for all $v \in O_{u}$ and $t \in \mathbb{R}_{+}$;

(ii) asymptotically stable (in sense of A.M. Lyapunov), if it is stable and for any point $\mathrm{v}$ in some neighborhood $v$ in some neighborhood $O_{u}$ of $u S(t, v) \rightarrow u$ for $t \rightarrow \infty$.

Definition 4. A functional $V \in C(\mathfrak{U}, \mathbb{R})$ is called a Lyapunov functional if

$$
\dot{V}(u)=\varlimsup_{t \rightarrow 0+} \frac{1}{t}(V(S(t, u))-V(u)) \leq 0 \quad \forall u \in O_{u} .
$$


Theorem 3. Let $u$ be a stationary point. If there exists a Lyapunov functional such that (i) $V(u)=0$;

$($ ii $) V(v) \geq \varphi(\|v-u\|)$; here $\varphi$ is strictly increasing continuous function such that $\varphi(0)=0$ and $\varphi(r)>0$ for $r \in \mathbb{R}_{+}$, then the point $u$ is stable.

Theorem 4. Let the conditions of Theorem (3) be satisfied, and a strictly increasing continuous function $\psi$ such that $\psi(0)=0$ and $\psi(r)>0$ for $r \in \mathbb{R}_{+}$. If $\dot{V}(v) \leq-\psi(\|v-u\|)$, then the point $u$ is asymptotically stable.

Lets consider two cases. Let $\lambda>0$, then the Lyapunov functional has the form:

$$
V=\int_{\Omega}\left(u_{x}^{2}+\lambda u^{2}\right) d x .
$$

Obviously $V(0)=0$. Given that $\lambda \in \mathbb{R}_{+}$, then $V(u) \geq c\|u\|_{\mathfrak{U}}^{2}$. Here $c=\min \{1, \lambda\}$. Hence, by the theorem (3) the point zero is stable. Further, considering that

$$
\dot{V}(u)=-2 \alpha\|u\|^{2}
$$

the point zero is asymptotically stable by the theorem (4).

Let $\lambda=0$. The phase space of problem (1)-(3) is $\mathfrak{U}^{1}$. We define a norm in this space as

$$
\|u\|^{2}=\int_{\Omega} u_{x}^{2} d x .
$$

We define the Lyapunov functional as $V(u)=\|u\|$. By the theorem (2) we obtain the stability of the zero point. Similarly to the previous arguments, we obtain that (8) is also satisfied. Hence a zero point is asymptotically stable. Thus, we have proved the theorem

Theorem 5. For all $\lambda \in \mathbb{R}_{+} \cup\{0\}, \alpha \in \mathbb{R}_{+}$zero solution of problem (1)-(3) is asymptotically stable.

\section{Numerical experiment}

Based on the theoretical results confirms the hypothesis about the instability of the zero solution of equation (1) in the system of computer mathematics Maple develop a program that allows you to: 1) find an approximate solution for the equation (1) based on specified coefficients; 2) get a graphical representation that illustrates the instability of the zero solution of (1).

To implement the program of computational algorithms, we used the built-in functions and standard Maple programming language statements. For obtaining a graphic image was connected plots package. At the first stage of the algorithm we define the coefficients of equation (1) and the number of elements the Galerkin approximation $\mathrm{m}$.

Lets consider the equation $(1)$ in domain $(0, \pi) \times \mathbb{R}$. Let the condition

$$
u(0, t)=u(\pi, t)=0, \quad t \in \mathbb{R} .
$$

We shall seek the solution of the problem (1), (9) in the form of a Galerkin sum

$$
u^{m}(t, x)=\sum_{k=1}^{m} u_{k}(t) \varphi_{k}, \quad m>1,
$$


here $\left\{\varphi_{k}\right\}$ is the set of solutions of the boundary-value eigenvalue problem

$$
\begin{gathered}
(\lambda-\Delta) u(x)=0, \quad x \in[0, \pi], \\
u(0)=u(\pi)=0 .
\end{gathered}
$$

It is solvable for a countable set of eigenvalues $\lambda_{k}$. A $\left\{\varphi_{k}\right\}$ is orthonormal (in the sense $L_{2}$ ) set of eigenfunctions corresponding to eigenvalues $\lambda_{k}$ of the homogeneous Dirichlet problem for the Laplace operator in $[0, \pi]$. It is easy to calculate that $\varphi_{k}=\varphi_{k}(x)=\sqrt{\frac{2}{\pi}} \sin (k x)$, $\lambda_{k}=-k^{2}$.

In the next step of the algorithm we will do scalar multiplication of equation (1) by the functions $\varphi_{k}$. We obtain a system of differential equations. We define initial conditions from a neighborhood of the point zero. Then we find a numerical solution of the Cauchy problem for a system of ordinary differential equations with initial conditions. Consider the Example.

Example 1. Find the numerical solution of the problem (1)-(3) if $m=2, \alpha=3, \lambda=-6$.

\section{Table}

Numerical solution of a system with initial conditions $u_{1}(0)=0.1, u_{2}(0)=0.1$

\begin{tabular}{|l|l|l|}
\hline$t$ & $u_{1}(t)$ & $u_{2}(t)$ \\
\hline 0.1 & 0.1061836547 & 0.1822118630 \\
\hline 0.2 & 0.1127496852 & 0.3320115504 \\
\hline 0.3 & 0.1197217363 & 0.6049643748 \\
\hline 0.4 & 0.1271249150 & 1.1023167850 \\
\hline 0.5 & 0.1349858808 & 2.0085518330 \\
\hline 0.6 & 0.1433329415 & 3.6598195096 \\
\hline 0.7 & 0.1521961556 & 6.6686249462 \\
\hline 0.8 & 0.1616074402 & 12.151025098 \\
\hline 0.9 & 0.1716006862 & 22.140608038 \\
\hline 1.0 & 0.1822118800 & 40.342812298 \\
\hline 1.1 & 0.1934792334 & 73.509386136 \\
\hline 1.2 & 0.2054433211 & 133.94281526 \\
\hline 1.3 & 0.2181472265 & 244.05968700 \\
\hline 1.4 & 0.2316366977 & 444.70568085 \\
\hline 1.5 & 0.2459603111 & 810.30646675 \\
\hline 1.6 & 0.2611696473 & 1476.4744405 \\
\hline 1.7 & 0.2773194764 & 2690.3114669 \\
\hline
\end{tabular}

If $m=2$, then taking into account condition (11), we will get

$$
u(x, t)=u_{1}(t) \sqrt{\frac{2}{\pi}} \sin x+u_{2}(t) \sqrt{\frac{2}{\pi}} \sin 2 x .
$$


Lets do the scalar multiplication of equation (1) by the functions $\varphi_{k}(k=1,2)$. We obtain a system of differential equations.

$$
\left\{\begin{array}{l}
-\frac{5}{2} \sqrt{2 \pi} \dot{u}_{1}(t)+\frac{3}{2} \sqrt{2 \pi} u_{1}(t)=0 \\
-\sqrt{2 \pi} \dot{u}_{2}(t)+6 \sqrt{2 \pi} u_{2}(t)=0 .
\end{array}\right.
$$

Obviously $u_{1}(t)=0, u_{2}(t)=0$ is a stationary solution of system. We define initial conditions from a neighborhood of the point zero. Let $u_{01}(t)=0.1, u_{02}(t)=0.1$. We solve the Cauchy problem for this system. Some of the resulting values will be given in the Table $u_{1}(t)$ and $u_{2}(t)$.

Fig. is a graphic interpretation of a fixed value of the parameter $\mathrm{x}$.

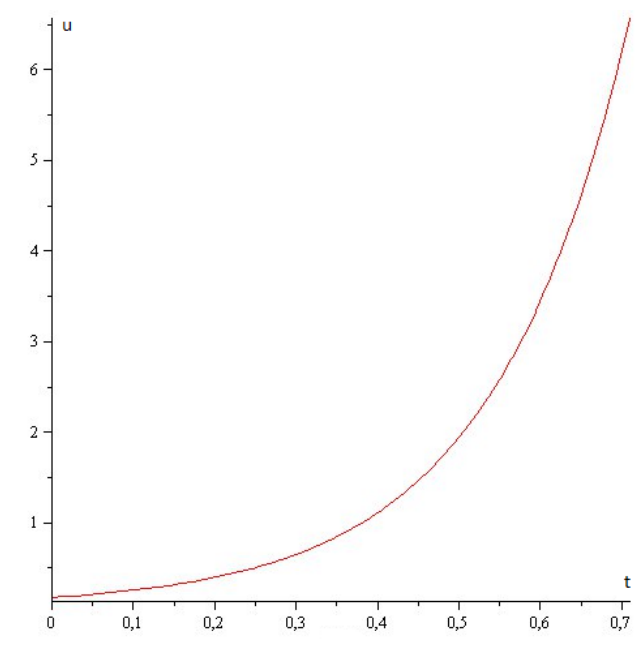

Fig. The dependence function $u$ of the parameter $t$.

This does not violate the generality of the results (for other values of $\mathrm{x}$ the situation is similar). A computational experiment illustrates that if $t \rightarrow \infty$ then the value of the function $u(x, t)$ increases exponentially and the stationary solution is unstable when $\lambda<0$.

\section{References}

1. Barenblatt G.I., Zheltov Yu.P., Kochina I.N. Basic Concepts in the Theory of Seepage of Homogeneous Fluids in Fissurized Rocks. Journal of Applied Mathematics and Mechanics, 1960, vol. 24, no. 5, pp. 1286-1303. doi: 10.1016/0021-8928(60)90107-6

2. Hallaire M. On a Theory of Moisture-Transfer. Inst. Rech. Agronom., 1964, no. 3, pp. 60-72.

3. Chen P.J., Gurtin M.E. On a Theory of Heat Conduction Involving Two Temperatures. Z. Angew. Math. Phys., 1968, vol. 19, pp. 614-627.

4. Keller A.V. [Investigation of Bounded Solution for Linear Equation of Sobolev Type]. PhD (Math) Work. Chelyabinsk, 1997. 115 p. (in Russian)

5. Sviridyuk G.A., Keller A.V. Invariant Spaces and Dichotomies of Solutions of a Class of Linear Equations of Sobolev Type. Russian Mathematics, 1997, vol. 41, no. 5, pp. 57-65. (in Russian) 
6. Shipilov A.S. On Stability Of Solutions To The Barenblatt-Zheltova-Kochina Equations Defined On Geometrical Graph. Bulletin of the South Ural State University. Series: Mathematical modelling, programming and computer software, 2008, no. 15 (115), issue 1, pp. 106-110. (in Russian)

7. Zagrebina S.A., Pivovarova P.O. The Second Lyapunov Method in Normed Spaces. Voronezhskaya zimnyaya matematicheskaya shkola [Voronezh Winter Matematical School]. Voronezh, 2010, pp. 50-60. (in Russian)

8. Sviridyuk G.A., Fedorov V.E. Linear Sobolev Type Equations and Degenerate Semigroups of Operators. Utrecht, Boston, VSP, 2003. doi: 10.1515/9783110915501

9. Sviridyuk G.A., Yakupov M.M. The Phase Space of an Initial-Boundary Value Problem for the Oskolkov System. Differential Equations, 1996, vol. 32, no. 11, pp. 1535-1540.

10. Sviridyuk G.A., Zamyshlyaeva A.A. The Phase Spaces of a Class of Linear Higher-Order Sobolev Type Equations. Differential Equations, 2006, vol. 42, no. 2, pp. 269-278. doi: 10.1134/S0012266106020145

11. Manakova N.A., Sviridyuk G.A. Nonclassical Equations of Mathematical Physics. Phase Space of Semilinear Sobolev Type Equations Bulletin of the South Ural State University. Series: Mathematics. Mechanics. Physics, 2016, vol. 8, no. 3, pp. 31-51. doi: 10.14529/mmph160304 (in Russian)

Polina O. Moskvicheva, PhD (Math), Associate Professor, Department of Equations of Mathematical Physics, South Ural State University (Chelyabinsk, Russian Federation), pelageia@bk.ru

Received May 25, 2017

УДК 517.9

DOI: $10.14529 /$ jcem 170204

\section{ВЫЧИСЛИТЕЛЬНЫЙ ЭКСПЕРИМЕНТ ДЛЯ УРАВНЕНИЯ БАРЕНБЛАТТА - ЖЕЛТОВА - КОЧИНОЙ В ОГРАНИЧЕННОЙ ОБЛАСТИ}

\section{П.О. Москвичева}

Исследование устойчивости уравнений соболевского типа несомненно является актуальной задачей, поскольку данные уравнения вместе с различными условиями моделируют множество процессов. Так, например, модель Баренблатта - Желтова - Кочиной описывает такие процессы, как, например, фильтрация и теплопроводность. В данной работе мы рассмотрим задачу Коши - Дирихле для данного уравнения, заданного в ограниченной области.

Устойчивость мы будем понимать в смысле Ляпунова. Целью данной работы является получение условий, при которых стационарное решение нашей задачи будет устойчиво и асимптотически устойчиво. Полученные условия сформулированы в теореме. Кроме того, будет описан алгоритм вычислительного эксперимента для иллюстрации неустойчивости в том случае, когда условия теоремы не выполнены. Заметим, что здесь применяется метод функционала Ляпунова, модифицированный для случая полных нормированных пространств. Вычислительный эксперимент основан на методе Галеркина.

Ключевые слова: уравнения соболевского типа, устойчивость. 


\section{Литература}

1. Баренблатт, Г.И. Об основных представлениях теории фильтрации в трещиноватых средах / Г.И. Баренблатт, Ю.П. Желтов, И.Н. Кочина // Прикладная математика и механика. - 1960. - Т. 24. № 5. - С. 58-73.

2. Hallaire, M. On a theory of moisture-transfer / M. Hallaire // Inst. Rech. Agronom. 1964. - № 3. - P. 60-72.

3. Chen, P.J. On a theory of heat conduction involving two temperatures / P.J. Chen, M.E. Gurtin // Z. Angew. Math. Phys. - 1968. - V. 19. - P. 614-627.

4. Келлер, А.В. Исследование ограниченных решений линейных уравнений типа Соболева: дис. канд. физ.-мат. наук / А.В. Келлер. - Челябинск, 1997.

5. Свиридюк, Г.А. Инвариантные пространства и дихотомии решений одного класса линейных уравнений типа Соболева / Г.А. Свиридюк, А.В. Келлер //Известия вузов. Математика. - 1997. - № 5. - С. 60-68.

6. Шипилов, А.С. Об устойчивости решений уравнений Баренблатта-ЖелтоваКочиной на геометрическом графе / А.С. Шипилов // Вестник ЮжноУральского государственного университета. Серия: Математическое моделирование и программирование. - 2008. - № 15 (115), вып. 1. - С. 106-110.

7. Загребина, С.А. Второй метод ляпунова в нормализованных пространствах / С.А. Загребина, П.О. Пивоварова // Воронежская зимняя математическая школа: тр. конф. - Воронеж: изд-во ВГУ, 2010. - С. 50-60.

8. Sviridyuk, G.A. Linear Sobolev Type Equations and Degenerate Semigroups of Operators / G.A. Sviridyuk, V.E. Fedorov. - Utrecht, Boston: VSP, 2003.

9. Sviridyuk, G.A. The Phase Space of an Initial-Boundary Value Problem for the Oskolkov System / G.A. Sviridyuk, M.M. Yakupov // Differential Equations. - 1996. V. 32, № 11. - P. 1535-1540.

10. Свиридюк, Г.А. Фазовые пространства одного класса линейных уравнений соболевского типа высокого порядка / Г.А. Свиридюк, А.А. Замышляева // Дифференциальные уравнения. - 2006. - Т. 42, № 2. - С. 252-260.

11. Манакова, Н.А. Неклассические уравнения математической физики. Фазовые пространства полулинейных уравнений соболевского типа / Н.А. Манакова, Г.А. Свиридюк // Вестник Южно-Уральского государственного университета. Серия: Математика. Механика. Физка. - 2016. - Т. 8, № 3. - С. 31-51.

Москвичева Полина Олеговна, кандидат физико-математических наук, дочент, кафедра уравнений математической физики, Южн-Уральский государственный университет (г. Челябинск, Российская Федерация), pelageia@bk.ru

Поступила в редакцию 25 мая 2017 г. 